\title{
Law Protection And Criminal Responsibility Of Land Deed Official (PPAT) On The Deed He Made
}

\author{
Fajar Fitrio Dwi Nugroho ${ }^{1}$ and Amin Purnawan ${ }^{2}$
}

Abstract. The purpose of this study was to analyze the responsibility of PPAT, the precautionary principle and law protection of PPAT on deed made (case study in State Court of Salatiga Decision 43 /Pdt.G/2017/PN. SIt). The approach used in this study is a sociological juridical methods with specifications this study uses descriptive analytical type. Data collection techniques using primary data through interviews and secondary data is by doing an inventory of the literature books, documents, articles. Qualitative analysis techniques. The results show based protection against PPAT, PPAT entitled to legal protection such as safety, both in mind and physical harassment and threats from others. PPAT parties responsible for the deed he made that is in accordance with the rules and principles PPAT deed and responsible to attend the hearing. Based on the precautionary principle PPAT less cautious in making payment of the memorandum of land. The results show based protection against PPAT, PPAT entitled to legal protection such as safety, both in mind and physical harassment and threats from others. PPAT parties responsible for the deed he made that is in accordance with the rules and principles PPAT deed and responsible to attend the hearing. Based on the precautionary principle PPAT less cautious in making payment of the memorandum of land. The results show based protection against PPAT, PPAT entitled to legal protection such as safety, both in mind and physical harassment and threats from others. PPAT parties responsible for the deed he made that is in accordance with the rules and principles PPAT deed and responsible to attend the hearing. Based on the precautionary principle PPAT less cautious in making payment of the memorandum of land.

Keywords: PPAT; Legal Protection; PPAT Responsibility; Precautionary Principle.

\section{Introduction}

Land Deed Official, hereinafter called PPAT is a public official who is authorized to make the deeds of authentic regarding certain legal actions regarding land rights or Top Properties Unit Flats. ${ }^{3}$

Land Deed Official (PPAT) in carrying out its duties and responsibilities under PP 24 of 2016 on the Amendment of the PP 37 of 1998 on regulations Land Deed Official, but in practice it often happens deed which is not in accordance with the procedure PPAT deed. The legal consequences of such deviations would put a PPAT held criminally accountable related to the deed he made. At this level of legal protection against PPAT aspect is not strictly regulated by the Position Rules PPAT. ${ }^{4}$

\footnotetext{
${ }^{1}$ Student of Master of Law, Universitas Islam Sultan Agung Semarang and Law Practitioner, email: fajarfitriodwinugroho@gmail.com

${ }^{2}$ Lecturer of Master of Law, Sultan Agung Islamic University (UNISSULA), Semarang

${ }^{3}$ Irawan Soerodjo. 2003. Kepastian Hukum Pendaftaran Hak Atas Tanah di Indonesia. Surabaya: Arkola.

${ }^{4}$ Iswahyudi Adipradana, Anwar Borahima dan Nurfaidah Said, 2018. Perlindungan Hukum Bagi Pejabat Pembuat Akta Tanah Sebagai Pemegang Polis Asuransi Profesi, Notaire: Vol. 1 No. 2, p. 251-268
} 
That does not happen things that are not desirable, PPAT in a deed must prioritize the precautionary principle $e^{5}$, forms the principle of precautionary (prudential principle) is supposed to do notary in the deed that is, doing an introduction to identity client, verify carefully the data subject and object client, giving a grace period in the execution of the deed, act cautiously, carefully and meticulous in the process of deeds, meet all the technical requirements deed and report if there are indications of money laundering in the transaction at the notary, forms the precautionary principle as it should responsible implemented notary so that later the notary can prevent problems law against the authentic deed made in the future. ${ }^{6}$

Pursuant State Court of Salatiga Decision No. 43 /Pdt.G/2017/PN. SIt. However, based on the case of a lawsuit otherwise vague, because as a boundary object lawsuit is not specified. Defendant I indicated involvement many cases. Decision 43 /Pdt.G/2017/PN. SIt, can still be filed again by creating a new lawsuit. Male defendant I have known a long time and close to the plaintiff, possibility no specific agreement between the plaintiff and the first defendant of this case behind PPAT. According to the judge who tried the case, the process undertaken by the procedural PPAT already in a sense already as agreed by the parties. PPAT in this case as a co-defendant (the second defendant), in this case in full knowledge of PPAT.

Based on the case of PPAT, this study focused on products that are in the form of law PPAT deed in which there is a dispute / sued in the future. The extent to which responsibility PPAT and involvement in this as the precautionary principle PPAT in making PPAT deed and legal protection, especially in this case.

Based on the background of the above problems, the formulation of the problem can be stated as follows: What legal protection, PPAT criminal responsibility and the application of the precautionary principle PPAT in a deed. The research objective to analyze the legal protection, PPAT criminal responsibility and the application of the precautionary principle PPAT in a deed. This research can be used or provide benefits to contribute ideas to the PPAT in performing their duties and profession, especially in making unlawful.

\section{Research Methods}

The approach used in this study is a sociological juridical methods. Specifications This research uses descriptive analytical type which provides an overview of research, writing and reported an object or an event and take the general conclusions of the issues discussed.

The required data sources of primary data obtained directly from the resource by means of interviews. Legal materials are used as secondary materials sourced from the legislation, namely: Act No. 5 of 1960 regarding the agrarian fundamental basis of Act No. 4 of 1996 on Mortgage there is a provision concerning the position and duties of

\footnotetext{
${ }^{5}$ Hatta Isnaini Wahyu Utomo dan Hendry Dwicahyo Wanda. 2017. Prinsip Kehati-Hatian Pejabat Pembuat Akta Tanah dalam Peralihan Tanah yang Belum Bersertifikat, Jurnal Hukum IUS QUIA IUSTUM NO. 3 Vol. 24 Juli 2017, p.467-487

${ }^{6}$ Ida Bagus Paramaningrat Manuaba, I Wayan Parsa, I Gusti Ketut Ariawan, 2018. Rinsip Kehati-Hatian Notaris Dalam Membuat Akta Autentik. Jurnal Ilmiah Prodi Magister Kenotariatan. Vol. 1 No.1, p.59-74
} 
PPAT and its implementation. 2) Regulation No. M.03.HT.03.10 Menkumham 2007 on making Minuta Deed and Dialing PPAT. 3) of Government Regulation No. 37 of 1998 on the Regulation of Land Deed Official Position. 4) of Government Regulation No. 24 of 1997 on Land Registration. 5) The decision of the Constitutional Court Number 49 / PPU-X / 2012 Legal Materials Tertiary ie dictionaries Indonesian Dictionary and Dictionary of Law.

Methods of collecting primary data with a personal interview that the authorities find out directly from the field. While the secondary data obtained by conducting an inventory of the literature books, documents, articles and various materials that have been acquired, recorded and then studied based on the relevance of-its relevance to the subject matter under study and then make an assessment as a whole.

Methods of qualitative data analysts, the analysis done by understanding and arranging data have been obtained and systematic, then be deduced. The conclusions drawn by using deductive thinking, namely the fundamental way of thinking on matters of a general nature and then be deduced in particular.

\section{Results and Discussion}

\subsection{Legal Protection of Land Deed Official (PPAT)}

Based on case No. 43 / Pdt.G / 2017 / PN.Slt PPAT as second defendant, loss good name tainted by the party I. Thus, PPAT as the second defendant are entitled to legal protection. Protection law in question is a variety of legal remedies that must be provided by law enforcement agencies to provide security, both in mind and physical harassment and threats from any party. In addition to legal protection there are several principles in the Criminal Code, one of which is the presumption of innocence (presumption of innocence), this principle is mentioned in the Act No. 14 of 1970 on the provisions of the Principal Judicial Power and also in the general explanation point 3c Criminal Procedure Code, which reads: ${ }^{7}$

"Any persons suspected, arrested, detained, prosecuted or faced in the face of the court, shall be considered innocent until the court ruling that declared his guilt and obtained permanent legal force."

PPAT legal protection against lawsuits over the deed made protected by the Code of Penal is liable to error element (intentional and negligence) as contained in Article 1365 of the Civil Code. ${ }^{8}$

In connection with the implementation of the duty office of a PPAT the aspects of the legal protection arrangements need to be allocated in the positive law of Indonesia. Philipus M. Hadjon argues that legal protection is the protection of the dignity and the recognition of human rights possessed by law subject to state law based on the legal provisions in force in the country in order to prevent arbitrariness. Legal protection is generally in the form of a written rule, so it is more binding and will result in sanctions

\footnotetext{
${ }^{7}$ Andi Hamzah, 1996, Hukum Acara Pidana Indonesia, CV Sapta Artha Jaya, Jakarta, p. 12

${ }^{8}$ Satjipto Rahardjo, Sisi-sisi Lain dari Hukum di Indonesia, Kompas, Jakarta, 2003,p.121
} 
that should be imposed on those who violate them. ${ }^{9}$

The concept of legal protection against PPAT can not be separated from the concept of legal protection in general. Based on that conception as a framework by basing on Pancasila, the principle of legal protection in Indonesia is the recognition and protection of human dignity rooted in the rule of law, which is based on Pancasila.

\subsection{Criminal Responsibility of PPAT Against The Deed That He Made}

Based on a case by case No. 43 / Pdt.G / 2017 / PN.Slt claim otherwise vague, because as a boundary object lawsuit is not specified. Defendant I indicated involvement many cases. Decision 43 /Pdt.G/2017/PN. Slt, can still be filed again by creating a new lawsuit. Male defendant I have known a long time and close to the plaintiff, possibility no specific agreement between the plaintiff and the first defendant of this case behind PPAT.

Based on the Decision 43 /Pdt.G/2017/PN. Slt, conducted PPAT is correct. PPAT had acted in accordance trustworthy and honest, thorough, independent, impartial and safeguard the interests of the parties involved in the legal action. After PPAT appropriate action as stipulated in Article 16 letter a revision of the Act of 2004 concerning Position Nomor. 30 PPAT to assert its obligation to act trustworthy, honest, thorough, independent, impartial and safeguard the interests of the parties involved in the legal action. PPAT role as the Act requires the PPAT position should a high moral integrity, honesty, and put priority on professional code of ethics. In principle, every command of legislation must be executed in order to create regularity.

Decision 43 /Pdt.G/2017/PN PPAT deed. Slt in accordance with the Law Act against PPAT criminal liability may be requested if the three conditions referred to above are affected collectively, meaning that on the one hand PPAT meet the elements have committed an offense against the Criminal Code and on the other hand PPAT also violated UUJN.

Accounts of crimes committed by PPAT in this case is based on an element of negligence such as that expressed by Munir Fuady the action that have done by PPAT included in act of negligence, ie too believe what was said by the first defendant, which does not settle the payment in accordance with the agreement. The sole liability under Munir Fuady divided into three namely: liable to error element (intentional and negligence) as contained in Article 1365 of Code of criminal responsibility by error element in particular omission as contained in Article 1366 of the Civil Code and the responsibility is absolute (without error) as contained in Article 1367 of the Civil Code. Accounted deeds of PPAT is negligence by the parties I believe, based on Islamic law does not violate the act PPAT Surah Al Baqarah verse 282 And Morals of Islam. The act of how prohibited for PPAT according to Surah Al Baqarah verse 282 And Morals Islam, Compliance Code PPAT Indonesia With Command Surah Al Baqarah Verse 282 And Morals of Islam. Letter relationships Al Baqarah verse 282 with PPAT profession is strong. There are similarities between PPAT in UUJN with Surah Al Baqarah Verse 282.

\footnotetext{
${ }^{9}$ Philipus M. Hadjon, Perlindungan hukum bagi rakyat di Indonesia, sebuah studi tentang prinsip-prinsip penanganannya oleh pengadilan dalam lingkungan peradilan umum dan pembentukan peradilan administrasi, Peradaban, Surabaya, 2007, p.205.
} 
In Surah Al Baqarah verse 282 in running his belt by ordinances and ethics that have been determined by Allah that of which to be honest is impartial and not detrimental to the parties, as well as PPAT profession that is tied by law and code of ethics office PPAT.

The principles of the profession PPAT has been set in advance in Islam this is indicated by the command recording land transactions. Prohibited for a PPAT in the womb of Surah Al Baqarah verse 282, among others: prohibited from doing injustice and partiality, and were forbidden to write does not fit the rules of writing. Do not be reluctant writer to write as God taught him. Let him not reducing the bit rather than debt; Do witnesses were reluctant (to testify) if they are called; Disdain not to reduce the debt write, both small and large until the deadline to pay; Do the authors witness suffer difficult; and Do you (witnesses) hide the testimony. Basically most of the contents of Surah Al Baqarah is already contained in the Code PPAT Indonesia, although there are still contained such provisions on the witness particularly the issue of male witnesses and witnesses determination to go through the approval of the client. Here we can draw the conclusion that most of the contents of the content of Surah Al Baqarah verse 282 contained in the Code of PPAT Indonesia.

The meaning and function of PPAT Deed Agreement in Sharia Law Study of the phenomenon of PPAT deed contract in Sharia law means the merger of the two poles of the law is civil law western and Islamic civil law. This phenomenon can not be separated by more existence and recognition of Sharia law in Indonesia that in fact predominantly Muslim Indonesia although the country is not an Islamic state.

The rules of Islamic law by promoting the principle of muamalah specifically this principle is categorized into 2 (two), among other things first, things are forbidden to be done in the activities muamalah that is the object of trade or commerce must be lawful and thayyib he has decided or will (antaradhin) and management mandate. ${ }^{10}$ The concept of halal objects emphasize the element of doing business is lawful and not prohibited by Islam such as selling liquor, unclean, tools and other gambling. Preferences propped up by the legal norms of Islam is not just to meet the desires on personal profit.

\subsection{The Principle of Precautionary In Deeds Making}

Based on the Decision 43 /Pdt.G/2017/PN. Slt explained that upon persuasion by the first Defendant Plaintiff Defendant I follow willingness to perform under the name of the object of dispute be on behalf of Defendant I, because Plaintiff intends to pay off immediately in the underpayment of buying and selling, as already agreed between the Plaintiff by the Defendant party I; To complete the requirements behind the name on the disputed through and PPAT Ani Isnawati, SH, M.Kn / Defendant II, then by the second defendant had published the deed of sale Buy with made as payment will be paid at a price of Rp. 285000 000,- (two hundred and eighty five million Rupiah) that this is not in accordance with the agreement between the plaintiff and the Defendant I.

\footnotetext{
${ }^{10}$ Djamil, Faturrahman. 2012. Penyelesaian Pembiayaan Bermasalah di Bank Syariah. Sinar Grafika : Jakarta
} 
The precautionary principle in this study regarding the case of PPAT (the second defendant). According to the judge who tried the case, the process undertaken by the procedural PPAT already in a sense already as agreed by the parties. PPAT in this case as a co-defendant (the second defendant), in this case PPAT knowledge paid off, so the act PPAT is in conformity with the Law of the Republic of Indonesia Number 30 Of 2004 on Position PPAT Article 16, paragraph (1).

As stated Law of the Republic of Indonesia Number 30 Of 2004 on Position PPAT Article 16, paragraph (1). In this case PPAT has done an honest, thorough, independent, impartial, and safeguard the interests of those involved in the legal action.

In the Position Rules PPAT there is a provision that ordered PPAT apply the precautionary principle in the execution of their office, namely in Article 22 of the Position Rules PPAT states that "Deeds PPAT should be read / explained its contents to the parties in the presence of at least two witnesses before they are signed immediately it is also by the parties, witnesses and PPAT. " The provisions in Article 22 of the Regulation of PPAT position when translated will find the formula that PPAT deed must a) Presented or explained its contents; b) In making must be attended by two witnesses; c) Signed by the parties, witnesses and PPAT.

In addition, Article 23 Paragraph (1) is described on the precautionary principle of "PPAT banned a deed, if PPAT myself, husband or wife, her family by blood or marriage, in a straight line without limitation the degree and in the line to the side to the second degree, become a party to the legal act in question, either by acting alone or through the power, or become a power of the other party. "

Many provisions of Islamic law which charged the precautionary principle or principles of ethical Islamic trying inevitably also have to be adopted by the PPAT. Among other provisions stipulated in the Qur'an Surah Al-Maidah verse 49 and Hadith Al-Tabarani history, which means as follows: Al-Quran Surah Al-Maidah verse 49 "And be ye judge between them by what Allah hath revealed, and follow not their desires. And be careful you against them, so that they do not turn you from a part what Allah has revealed to you ..."

Hadith Al-Tabarani History

"The caution that comes from God, otherwise careless attitude that comes from Satan" (HR. Al-Tabarani)

Those principles will be more perfect if in practice coincided with the principles of trying, as guided by the Qur'an and the Sunnah of the Prophet. If these principles run the risk that is harmful. Implementation of the provisions or principles consistently will bring and or ensure the existence of PPAT, which ultimately public confidence in the PPAT will increase.

\section{Closing}

\subsection{Conclusion}

- Based on case No. 43 / Pdt.G / 2017 / PN.Slt PPAT as second defendant, loss good name tainted by the I. Thus, PPAT as the second defendant are entitled to legal protection. Protection law in question is a variety of legal remedies that must be 
provided by law enforcement agencies to provide security, both in mind and physical harassment and threats from the others.

- Based on the Decision 43 /Pdt.G/2017/PN. Slt, it can be disclosed that, the procedure is done PPAT in making or a deed is in conformity with the procedures, so PPAT not proven guilty. However PPAT was ethically responsible for the deed he made that is in accordance with the rules and principles PPAT deed and responsible to attend the trial

- The precautionary principle in this study regarding the case of PPAT (the second defendant). According to the judge who tried the case, the process undertaken by the procedural PPAT already in a sense already as agreed by the parties. PPAT in this case as a co-defendant (the second defendant), in this case PPAT knowledge paid off, so the act PPAT is in conformity with the Law of the Republic of Indonesia Number 30 Of 2004 on Position PPAT Article 16, paragraph (1).

\subsection{Suggestion}

- It is expected to always be careful and do the checking before processing the land purchase to return the name of the certificate on the ground. PPAT should not be arbitrary in processing land purchase land selling mainly forgery, because basically PPAT should ensure that all of the completeness of the terms of a purchase and return the name of the land certificate has been fulfilled properly. It is thus the process can go smoothly and will not have problems / disputes in the future.

- Because PPAT is a public authority entrusted to him in terms of making authentic act which ensures legal certainty on the rights and obligations of the parties to take legal actions, then PPAT should have the nature of an honest, have good faith and be professional and must cling to the rules legislation and subject to the code of professional conduct and take responsibility for the validity of the authentic made.

\section{References}

[1] Andi Hamzah, 1996, Hukum Acara Pidana Indonesia, CV Sapta Artha Jaya, Jakarta

[2] Djamil, Faturrahman. 2012. Penyelesaian Pembiayaan Bermasalah di Bank Syariah. Sinar Grafika : Jakarta

[3] Hatta Isnaini Wahyu Utomo dan Hendry Dwicahyo Wanda. 2017. Prinsip KehatiHatian Pejabat Pembuat Akta Tanah dalam Peralihan Tanah yang Belum Bersertifikat, Jurnal Hukum IUS QUIA IUSTUM NO. 3 Vol. 24 Juli 2017

[4] Ida Bagus Paramaningrat Manuaba, I Wayan Parsa, I Gusti Ketut Ariawan, 2018. Rinsip Kehati-Hatian Notaris Dalam Membuat Akta Autentik. Jurnal IImiah Prodi Magister Kenotariatan. Vol. 1 No.1.

[5] Irawan Soerodjo. 2003. Kepastian Hukum Pendaftaran Hak Atas Tanah di Indonesia. Surabaya: Arkola.

[6] Iswahyudi Adipradana, Anwar Borahima dan Nurfaidah Said, 2018. Perlindungan Hukum Bagi Pejabat Pembuat Akta Tanah Sebagai Pemegang Polis Asuransi Profesi, Notaire: Vol. 1 No. 2 
Jurnal Daulat Hukum: Volume 2 Issue 4, December 2019 : 593 - 600

[7] Philipus M. Hadjon, Perlindungan hukum bagi rakyat di Indonesia, sebuah studi tentang prinsip-prinsip penanganannya oleh pengadilan dalam lingkungan peradilan umum dan pembentukan peradilan administrasi, Peradaban, Surabaya, 2007

[8] Satjipto Rahardjo, Sisi-sisi Lain dari Hukum di Indonesia, Kompas, Jakarta, 2003 